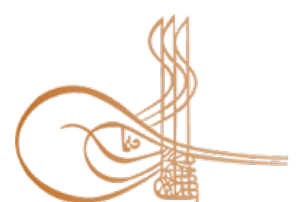

www.turkishstudies.net/history
Turkish Studies - Historical Analysis

eISSN: 2667-5552

Research Article / Araștırma Makalesi

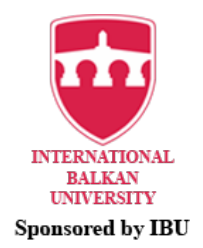

Sponsored by IBU

\title{
Meclis Çalışmaları Kapsamında Amasya Mebusu Ömer Lütfi Bey'in "Bilûmum Şirketlerde Türkçe Lisanı’nın Kullanılmasına Dair” Kanun Teklifi Üzerine Mecliste Yapılan Tartışmalar
}

Discussions in the Parliament on the Bill of Amasya Parliament Member Ömer Lütfi Bey on "The Use of the Turkish Language in All Companies" Within The scope of the Parliamentary Studies

\author{
Turgut İleri*
}

\begin{abstract}
Religios, political, social and cultural relations have been established with the Islamic World in the nearby geography during the Anatolian Principalities and later in the Ottoman Empire. As a result of these established and developed relationships, the Arabic and Persian languages used in this environment have had an impact on the Turkish Language. In order to remove the influence of these languages on the Turkish Language, some measures were taken both by the statesmen during the principalities and the Ottoman period. On the other hand, especially the increase in commercial relations with the western world caused the languages of the western states to be used and spoken in the Ottoman country. All agreements, communication and proceses with these foreign companies were made with their native language. The written documents based on the bilateral agreements and prepared only in foreign language caused a lot of problems in bureauracy. The items in the agreements were misunderstood and it lead foreign companies to use these misunderstandings on their own benefits. It was decided to write one copy of the agreements in foreign language and the other copy in Turkish language to prevent these misunderstandings. Later on, in 1916, a law was announced that all agreements and processes with the privilaged and unprivilaged companies had to be written in Turkish. The issue was brought to the agenda of the Turkish Grand Assembly. In this Study, it is aimed to give information about the discussions performed in Turkish Grand Assembly about the Bill of Amasya member of Parliament Ömer Lütfi Bey on " using Turkish Language in all companies".
\end{abstract}

Structured Abstract: In this study, it is aimed to explain the discussions held in Turkish Grand Assembly about using Turkish language and becoming it the dominant language for all types of communication with the foreign companies inherited from the Ottoman period. It is also aimed to give information about these discussions and proposals after the subject was brought to the agenda of Turkish Grand Assembly by Ömer Lütfi Bey, Member of Parliament of Amasya.

During the reformist period, the foreign companies gained and increased new rights on trade and these privileges made them become dominant in trade. This provided them to use their own native language in all types of processes. Many commercial agreements were made especially with English and French companies within this period. These agreements involve the construction of the railways, operation of electric and tram

\footnotetext{
* Dr.Öğr. Üyesi, Amasya Üniversitesi, Eğitim Fakültesi, Türkçe ve Sosyal Bilimler Eğitimi Bölümü. Asts. Prof., Amasya University, Faculty of Education, Turkish and Social Sciences Education Department. ORCID 0000-0003-2029-1354

turgut.ileri@amasya.edu.tr

Cite as/ Atıf: İleri, T. (2020). Meclis çalışmaları kapsamında Amasya Mebusu Ömer Lütfi Bey’in "Bilûmum Şirketlerde Türkçe Lisanı’nın Kullanılmasına Dair " Kanun teklifi üzerine mecliste yapılan tartışmalar. Turkish Studies - History, 15(2), 515-531. https://dx.doi.org/10.29228/TurkishStudies.42777

Received/Geliş: 06 April/Nisan 2020

Accepted/Kabul: 20 June/Haziran 2020

Copyright $($ INTAC LTD, Turkey
} 
systems and the construction of telephone, telegraph, natural gas and water systems. These foreign companies used their own native language in all documents of these commercial agreements. Using their own native language in the documents of these commercial agreements caused some misunderstanding based on the bilateral relations. It lead misunderstanding in the items of the documents and the foreign companies used these misunderstanding on their own benefit. These negative sides caused some harms in economical point of view. It was decided to type one copy of these documents in foreign language and the other copy in Turkish to prevent these misunderstanding. Such a case prevented the misunderstandings and the foreign companies could not use them for their own benefit. It also made the Turkish language effective and made the country independent by yielding a connection between the language and the independence.

In the last years of the Ottoman Empire, it was compulsory to type the commercial documents made with the foreign companies in Turkish in the first constitution of Ottoman Empire called "Kanun-i Esasi" and it helps the Turkish language to be official language of the country. Using and speaking Turkish language caused some discussions in the II. Reformist Period. As known before, the İttihat and Terakki political party had a right to say about ruling the country in II. Reformist Period. In the policy of the political party, it was important to provide collectiveness within the country. Using Turkish language widely among the people within the country was one of the methods to provide the collectiveness.

The discussions made in the Parliament were mostly about to make the Turkish language official language of the country. The laws made in the sessions could not be understood by the people whose languages were not Turkish and it caused chaos in the sessions. These laws later translated into local languages to provide these people to understand them and then they were announced. After these developments, a new law was declared that the privileged and unprivileged companies had to use Turkish in all kinds of documents. It made compulsory to use Turkish in all documents and communications by the privileged and unprivileged companies in the borders of Ottoman Empire with the law declared 10th March 1332/23rd March 1916 in Takvim-i Vekayi.

Although there was a law about using Turkish in all documents declared on 23rd March, 1916 in Takvim-i Vekayi by the privileged and unprivileged companies within Ottoman Empire, it was not taken into account. Ömer Lütfi Bey, elected as a Member of Parliament of Amasya in the last Parliament of Ottoman Empire and in the Ist term of Turkish Grand Assembly, gave a proposal on 6th February 1923 about using Turkish in all companies. His proposal could not be discussed immediately because of the election of the 2 nd term Turkish Grand Assembly, but it was discussed 7 months later on 25th November, 1923. This proves us that there was a law about using Turkish in all companies declared in 1916 but, it could not be succeeded, it came up to 1923 in the same way. However, it was not accepted natural and it was taken into the agenda of Turkish Grand Assembly.

The Bill given by Ömer Lütfi Bey was discussed in two different sessions. In the first session, it was discussed to see whether there was a similar law beforehand and it was put into action. After these discussions, it was seen that there was a law declared on 23rd March, 1916 in Takvim-i Vekayi by the members of Parliament. The discussions were carried on about the presence of the law and its application within the country. The reason why it was not put into action was explained as the negative effect created by the war and the stress of the agreement period. The President of the Parliament made a proposal to end up all these discussions and to solve the problem. He proposed that as there was a law, a new law was not needed but, it was altered by a commission and the commission brought it to the Assembly in latest version. It was decided that the law had to be altered and brought to the Assembly.

Ömer Lütfi Bey played an important role to alter the forgotten law and to bring it again to the Assembly once more.

Keywords: Ömer Lütfi Bey, Turkish Language, Law Offer, TBMM, Amasya Member of Parliament.

Öz: Anadolu Beylikleri ve sonrasında Osmanlı Devleti Döneminde yakın coğrafyada bulunan İslam dünyası ile dinî, siyasî, sosyal ve kültürel ilişkiler kurulmuştur. Kurulan ve geliştirilen bu ilişkiler sonucunda bu çevrede kullanılan Arapça ve Farsça dilleri, Türk Dili üzerinde etkili olmuştur. Bu dillerin Türk Dili üzerindeki etkisini kaldırmak maksadı ile hem beylikler döneminde hem de Osmanlı Döneminde devlet adamları marifeti ile bir takım önlemler alınmıştır. Diğer taraftan batı dünyası ile özellikle ticarî ilişkilerin artması, batılı devletlerin dillerinin Osmanlı Ülkesinde kullanılır ve konuşulur olmasını yol açmıştır. Yabancı şirketlerle yapılan her türlü 
sözleşme, iletişim ve işlemler, ilgili devletlerin dilleri ile yapılmıştır. İkili anlaşmalara dayalı yazılı metinlerin yalnızca yabancı dilde hazırlanması bürokraside birçok sorunu beraberinde getirmiştir. Anlaşmada geçen hükümlerin yanlış anlaşılmasına, yabancı şirketlerin konuyu kendi çıkarlarına göre yorumlamalarına sebebiyet vermiştir. Bunun önlenmesi için anlaşma metinlerinin bir nüshasının yabancı dilde, diğer nüshasının Türkçe olmasına karar verilmiştir. Ardından 1916 yılında, imtiyazlı ve imtiyazsız şirketlerde tüm yazışma ve işlemlerin Türkçe yapılmasına dair bir kanun yayınlanmıştır. Ancak, savaş yıllarının ve ardından mütareke ortamının getirdiği olumsuzluklar kanunun uygulanmasında ihmallere yol açmıştır. Bu nedenle konu meclis gündemine getirilmiştir. Bu çalışmada, I. Dönem Amasya Milletvekili Ömer Lütfi Bey tarafından TBMM' ne sunulan "Bilûmum şirket ve müesseselerde Türkçe lisanının kullanılmasına dair kanun teklifi" üzerine mecliste yapılan tartışmalar hakkında bilgi verilecektir.

Anahtar Kelimeler: Ömer Lütfi Bey, Türk Dili, Kanun Teklifi, TBMM, Amasya Mebusu.

\section{Giriş}

Dil, bilindiği üzere tüm insanlar için bir iletişim aracı, insanların birbirleri ile anlaşmasında, duygu ve düşüncelerinin aktarılmasında ve kendini ifade etmesinde önemli bir vasıtadır. Bu genel tanım yanında Dil, "İnsanların düşündüklerini ve duyduklarını bildirmek için kelimelerle veya işaretlerle yaptıkları anlaşma; düşünce ve duyguları bildirmeye yarayan bir anlatım aracı" olarak da tanımlanmıştır (Türkçe Sözlük, 1998: 586). Bu tanımlar yanında Dil, "milletin manevi gücünün eseri, ruhunun da dış görünüşüdür" şeklinde ifade edilerek ona derin bir anlam yüklenmiştir (Korkmaz,2017a: 652). Bu kapsamda dil, millet olmanın önemli bir unsuru ve varlığının somut göstergesi, kaybedildiğinde de yaşama hakkının ortadan kalktığının işareti olarak nitelendirilmiştir (Ayverdi, 1976: 20). Dil ile ilgili tanımları birbirine benzer ifadeler ile daha da artırmak mümkündür. Dilin bir özelliği her toplumun veya her milletin kendine ait bir dilinin bulunmasıdır. Geçişgenlik özelliği gösteren topluluklarda birden fazla dilin varlığı ve kullanılması mümkündür. Özellikle çok uluslu devletlerde veya imparatorluklarda bu durum kaçınılmazdır. Uzun yıllar geniş alanlara hükmeden ve birçok farklı unsuru bünyesinde barındıran Osmanlı Devleti'nde de farklı dillerin konuşulması söz konusu olmuştur. Böyle olmakla beraber esas unsuru oluşturan Türkler'in konuştuğu dil Türkçe, hâkim dil özelliğini korumuştur. Ancak dönemin sosyal ve kültürel özelliğine bağlı olarak Arapça ve Farsça'nın Türk dili üzerinde önemli ölçüde etkisi olmuştur. Bu etkiyi kaldırmak, diğer taraftan da millî kültür ve şuuru oluşturmak amacıyla ciddi manada girişimlerde bulunulmuştur. $\mathrm{Bu}$ kapsamdaki girişim ve çalışmalara bilindiği kadarıyla Anadolu beylikleri döneminde başlanmıştır. Anadolu Selçuklu Sultanı II. İzzeddin Keykavus'un (1246-1261) halk arasında beğenilen ve oldukça yaygın olarak anlatılan destan mahiyetindeki "Danişmendnâme" adlı eseri, kendi yazıcısına Türk Dili ile yazdırması ilk defa Türkçeye verilen önemi göstermesi bakımından değerlidir (Banarlı, 1983: 299). Ardından, Karamanoğlu Mehmet Bey'in 1277 de Konya'y1 ele geçirdiğinde "Dergâh ve Bargâhda, mecliste ve meydanda Türkçeden başka dil konuşulmayacağına" ilişkin fermanı, bu konuda atılan adımlara gösterilen diğer bir örnektir. Bu fermanın ilanını, Türkçeyi ilk defa Devlet Dili olarak kabul etmeye yönelik bir hamle olarak görenlerin yanında, aslında bunun uygulanamadığını ve tek başına bu fermanın Türkçeyi Devlet Dili konumuna getirmeyeceğini ileri sürenler de olmuştur (Turan,1979: 352-353). Her şeye rağmen fermanın yayınlanmış olması, Anadolu Beyliklerinin genel tutumunu ve kültür seviyelerini ortaya koyması bakımından önemli görülmektedir (Korkmaz, 2017b:424-428).

Türk Dili konusunda başlatılan bu ilk girişimlerin ardından, Osmanlı Dönemi'nde Türkçe'nin devlet dili olması yolunda gösterilen çabalar da dikkate değerdir. Orhan Bey (1324-1362) zamanında vakfiyelerin Türkçe yazılması, konuya ehemmiyet verildiğini göstermektedir. Ardından Sultan II. Murat döneminde (1421-1451) benzer çalışmaların yapıldığı, telif ve tercüme faaliyetlerinin sürdürüldüğü ve nihayetinde Türkçe'nin devlet dili haline getirilmeye çalışıldığ görülmektedir. Tüm bunlardan başka bir kısım Osmanlı âliminin de yeni Müslüman olan gayr-i Müslimlerin eski dillerini terk etmeleri için fetva yayınlayarak Türkçeyi bir bakıma himaye etmeye 
çalışmaları bu kapsamdaki çalışmalardan sayılmaktadır (Turan,1979: 352-354). Fatih'in de devlet teşkilatını oluşturacak kanunların hazırlanması sırasında dil konusuna özellikle dikkat edilmesini istemesi bu konuya hassasiyet göstermesi ile ilgilidir (Acar, 2013: 97). Yine saray içinde devlet görevlilerinin yetiştirildiği bir okul olan Enderun'da tüm okutulan derslerin Türkçe olmas1, Türkçe'nin Devlet Dili yapılmasına yönelik gayretlerden biri olarak değerlendirilmektedir (Ergin,1977: 16).

Osmanlı Devleti'nde Tanzimat'a kadar gelen süreçte Türk Dili'ne gösterilen özen ve hassasiyet bir bakıma Türkçeyi Arapça ve Farsçanın baskısından kurtarmak, diline sahip çıkma şeklinde kendini göstermiştir. Bununla beraber dil ile bağımsızlık arasında var olan bağı güçlendirilerek, millî hassasiyet ortaya konmaya çalışılmıştır. Zira millet olma, milli bilinçlenme, bağımsızlığ elde etme ve bunu sürdürebilme, dilde millîleşme çaba ve hareketini de beraberinde getirmektedir (Erişen, 1979: 200-205). Dil, bilindiği üzere ulusal düşüncenin hem nedeni hem de sonucudur. Bütünleştirici ve birleştirici bir yönü olan dilin ülkenin bağımsızlığını devam ettirmedeki rolü asla hafife alınamaz. Bu nedenle pek çok devlet resmi dillerini koruma altına almak üzere çeşitli ölçekte yaptırımlara başvurmuşlardır (Şimşek, 2014: 739). Bu kapsamda Osmanlı Devleti'nde Tanzimat Dönemine kadarki süreçte Türk Diline güncellik kazandırılmaya yönelik belirgin bir çaba sarf edildiği görülmektedir.

Tanzimat Döneminde, Osmanlı'da özellikle bürokraside Türk Dilinin kullanılması ve Devlet Dili haline getirilmesi konusunda zorluklarla karşılaşılmıştır. Önceleri geleneksel kültür, sosyal ve siyasî hayatın bir sonucu olarak Arapça ve Farsçanın etkisinde kalan Türk Dili, bu dönemde batılı ülkelerle farklı ilişkilere girilmesi sonucu batı menşeli yabancı dillerin de etkisi altına girmiştir. $\mathrm{Bu}$ etki genellikle bürokraside kendini göstermiş, yabancı ülkelerin şirketleri ile yapılan anlaşmalarda ve kurulan ticari ilişkilerle ilgili hazırlanan tüm evrak ve belgelerde o ülkenin dili kullanılmıştır. İkili anlaşmalara dayalı yazılı metinlerin yalnızca yabancı dilde hazırlanması bürokraside birçok sorunu beraberinde getirmiştir. Anlaşmada geçen hükümlerin yanlış anlaşılmasına, yabancı şirketlerin konuyu kendi çıkarlarına göre yorumlamalarına sebebiyet vermiştir. $\mathrm{Bu}$ tür olumsuzluklar çoğu zaman ekonomik açıdan zararlara neden olmuştur. Yabancı yatırımcı ve ticari şirketlerle yaşanan bu sorunu çözmek için girişimlerde bulunulmuş, sonuçta anlaşma metinlerinde dilden kaynaklanan belirsizlikleri ortadan kaldırmak üzere yabancı dil yanında Türkçe'nin de kullanılmasına karar verilmiştir. Böylelikle en azından yabancı dillerin Türkçe üzerindeki etki ve hâkimiyetine engel konulmuştur (Günalan, 2016: 341).

Yabancı ülkelere ait şirketlerle anlaşma ve yazışmalarda Türkçe'nin kullanılmasına dair ilk resmî uygulamaların Tanzimat Döneminde başlatıldığ 1 görülmektedir. Özellikle Osmanlı Devleti'nde yabancı şirketlerin faal olduğu demiryolu, haberleşme ve su hizmetlerindeki tüm anlaşmaların Türkçe olmasına yönelik resmî adımlar bu dönemde atılmış, buyuruldular hazırlanmıştır. Ardından Kanun-î Esasinin hazırlanması aşamasında ve sonrasında II. Meşrutiyet Döneminde hem Türkçe'nin resmî dil olması hem de yabancı şirketlerle yapılan işlemlerde Türkçe'nin kullanılmasına yönelik gayretlerin sürdürüldüğ̈̈, bu isteğin Cumhuriyet ilan edilene kadar devam ettiği anlaşılmaktadır(Özçelik, 2002: 213-214. Bu bağlamda başta 1876 Kanun-i Esasi olmak üzere 1921 tarihli Teşkilat-1 Esasî Kanununda ve sonraki anayasalarımızda konuya açıklık getiren hükümlere yer verilmiştir (Acar, 2013: 114-115).

Yukarıda özetlendiği üzere, Türk Dili’nin yaygın olarak konuşulmasına, aynı zamanda yabancı ülkelerle yürütülen siyasi ve ticari yazışmalarda Türkçe'nin kullanılmasına yönelik çalışmaların yapılmasına ve konunun oldukça önemsenmesine rağmen uygulamada istenen başarının elde edilemediği anlaşılmaktadır. Gerek Osmanlı mebuslar meclisindeki 1909-1910 y1lı tartışmaları (M.M.Z.C., C. 6, 25 Mayıs 1326: 86-91), gerekse TBMM'deki 1923 yılında yapılan tartışmalar bu durumu kanitlamaktadır (TBMM.Z.C., C.IV, 31.12.1339: 572-577). 
Bu çalışmada, Osmanlı Döneminden intikal eden yabancı şirketlerle yapılan ticari, resmî ve tüm işlemlerde yazışmaların Türkçe yapılması ve Türkçe'nin her alanda hâkim dil haline getirilmesi kapsamında TBMM'deki çalışmalar ele alınacaktır. Bu bağlamda, Amasya Mebusu Ömer Lütfi Bey'in konuyu TBMM de gündeme getirmesi ile başlatılan tartışma, görüşme ve öneriler hakkında bilgi verilecektir.

\section{A- Osmanlı Döneminde Yabancı Şirketlerle Yapılan Anlaşma ve Yazışmalarda Türkçe'nin Kullanılmasına İlişkin Düzenlemeler}

Osmanlı Devleti, özellikle Tanzimat'ın ilanından sonra Batılı ülkelerle yakınlaşmış bu kapsamda sosyal, siyasi, ekonomik ve diplomasi ilişkileri kurup geliştirmiştir. Bu ilişkiler içinde ekonomik ve ticari ilişkiler konumuzla ilgili olması sebebiyle önem arzetmektedir. Bu devrede ağırlıklı olarak İngiliz ve Fransızlarla ticari anlaşmalar yapılmış, bu devletlere birtakım imtiyazlar tanınmıştır (Karluk, 1997: 195). Anlaşmalar ve imtiyazlara bağlı olarak Batıda sanayi devriminin gerçekleşmesi sonucu ortaya çıkan yeni buluşlar, insan hayatını kolaylaştıran yenilikler ve ihtiyaçlar bu devletler aracılığı ile Osmanlı Devleti'nde de hayata geçirilmeye çalışılmıştır. İhtiyaçlar içeresinde askerî olanları ilk sırayı almış, ticarî ve ziraî ihtiyaçlar bunu takip etmiştir. Ticari mahiyette olanlar içinde demiryolları hatlarının inşası, elektrik enerjisinin sağlanması, tramvay işletmelerinin oluşturulması, telefon, telgraf, havagazı ve su isale hatlarının inşası bulunmaktadır. Bunların inşası, yapımı ve işletilmeleri için imtiyazlı ve imtiyazsız ortaklıkların kurulması gerekmiştir. Osmanlı Devleti, kamu hizmetleri olarak görülen bu alandaki hizmetlerin yürütülmesini sağlamak amacı ile yabancı şirketlerle ya ortaklık kurmuş ya da imtiyazlar vermiştir (Tan, 1967:293295). Hizmetlerin yürütülmesi amacıyla hükümetin ilgili şirketlerle yapmış olduğu mukavelelerin meclisin onayı alınarak, yabancı şirketlerin mensup olduğu devletin resmî dili ile ve bir nüshasının da Türkçe hazırlanması kararlaştırılmıştır. Bu bağlamda hizmetleri satın alan halkla yapılan mukavele ile tüm işlemlere dair evrakların Türkçe hazırlanması uygulaması getirilmiştir (Günalan, 2016: 343).

Osmanlı Döneminde yabancı şirketlerle yapılan anlaşma ve yazışmalarda Türkçe'nin kullanılması ile ilgili belgelerden ilki, Osmanlı telgrafhanelerinde haberleşmenin Türkçe yapılmasına dair olan 11 Şaban 1273/6 Nisan 1857 tarihli buyruldu 'dur. Buyruldu, Maliye Nezaretine yazılmış olup, içeriğinde Fransız ve İngilizlere ait şirketler tarafından yapılan telgraf hattı ile telgrafhanelerde haberleşmenin Türkçe yapılacağ düzenleme İstanbul'un su sorununun çözmek amacıyla "Dersaadet Anonim Su Şirketi” adını taşıyan şirketle yapılan mukavelede görülmektedir. Hukukî ve idare merkezi İstanbul, fiili idare merkezi Paris olan bu Fransız şirketi ile yapılan imtiyaz anlaşmalarında Türkçe ve Fransızca birlikte kullanılmıştır. Yabancı şirketlerin işlemlerinde kendi dilleri ile hazırlanan evraklarına Türkçe tercümesinin de konulması gerekli kılınmıştır. Bununla birlikte idare merkezleri İstanbul'da bulunan bazı şirketler, hükümetle yazışmalarında genellikle Fransızcayı kullanmışlardır (BOA), (HR. TO.), 371/108).

Diğer taraftan öncelikle askerî amaçlı olmak üzere şehir ve kasabalarda inşa edilecek demiryolları ile alakalı olarak imtiyazlı yabancı şirketlerle yapılacak yazışmaların da Türkçe olmasına dair düzenlemelerin yapıldığını görmekteyiz. Bunlardan ilki, 25 Cemâziyelâhir 1310/14 Ocak 1893 tarihlidir. Belge Ticaret ve Nafia Nezaretlerine hitaben yazılmıştır. Belgede demiryolu işlerinin imtiyazlı yabancı şirketlere verilmesi durumunda biri Türkçe diğeri Fransızca olmak üzere iki adet defterin düzenlenmesi öngörülmektedir (BOA, (BEO), 139/10353). Konu ile bağlantılı yaklaşık yirmi yıl sonra hazırlanan iki adet belge daha vardır. Birbiri ile ilintili olan bu belgelerin biri 15 Eylül 1915 tarihli tezkire ile 22 Eylül 1915 tarihli zabıtnamedir. Her iki belge de özetle demiryolu şirketlerinin iç işlerdeki yazışmalarda Türkçe'yi kullanmaları bildirilmiştir (BOA, (M.V) 199/18). Uygulamanın sahadaki kontrolünü yapmak üzere Harbiye ve Nafia Nezaretlerinde görevli memurlardan oluşan bir komisyonun kurulmasına karar verilmiştir. Bu çalışmaların ardından önemli 
adımların atıldığı görülmektedir. 17 Ekim 1915 tarihinde Osmanlı Nafia Nezaretinden hükümete bir tezkire ile aynı maksada haiz Ticaret Müdüriyet-i Umumiyesi tarafından esbab-1 mûcibe mazbatası hazırlanmıştır. Her iki belgede Osmanlıda tüm demiryolları ile bayındırlık şirketlerinin yazışma ve işlemlerinde resmî dil olarak Türkçe'nin kullanılacağına yer verilmiştir ( BOA), (Ş.D), 512/1).

Hazırlanan mazbata ve layihalardan bütün malî, ticarî, bayındırlık ve denizcilik şirket ve kuruluşlarının tüm yazışma ve işlemleri ile tutulacak defter ve hesaplarında Türkçe'yi kullanmalarının zorunlu hale getirildiği anlaşılmaktadır. Ancak bu konuda tam olarak başarının elde edildiğini gösteren bilgiler maalesef yeterli değildir.

Türk topraklarında Türkçe'nin kullanılmasına ilişkin çabalar yanında Türkçe'nin resmî dil olması yolunda da önemli adımlar atılmıştır. Osmanlı Devleti'nde Türkçe'nin resmî dil kabul edilmesine yönelik gayretler, 1876 da kabul edilen Kanun-1 Esasi'nin hem taslak metninde hem de asıl metninde görülmektedir. Kanun-i Esasi taslağının 18. Maddesinde; Osmanlı tebaasından olup devlet hizmetinde bulunacakların devletin resmî dili olan Türkçe'yi bilmeleri şartı konmuştur (Kili ve Gözübüyük, 1985: 33). Anayasanın asıl metninde ise 57. Maddesinde; Meclis-i Mebusanda yapılacak olan konuşmaların Türkçe olması, 38. Maddesinde ise mebus seçileceklerin Türkçe bilmeleri şartı getirilmiştir (Acar, 2013: 98-101). Her ne kadar yabancı şirketlerin her türlü işlemlerinde Türkçe kullanmalarına yönelik hükümler yer almamışsa da meclis ve meclisle bağlantılı olan kimseler için kullanılacak dil ile ilgili şartların konduğu görülmektedir.

Türkçe'nin konuşulması ve kullanılmasına dair tartışmalar II. Meşrutiyet döneminde de devam etmiştir. 1910 yılında Meclis-i Mebusan'da "Kavanin ve Nizâmatın Suret-i Neşr ve İlanı Hakkında Kanun Layihası" nın görüşülmesi sırasında Türkçe üzerine tartışmalar yapılmıştır. Bu oturumda yapılan tartışmalar genellikle Türkçe'nin resmî dil olması ile ilgili olup, ana dili Türkçe olmayanların meclisten çıkan kanunları anlayamadıkları, dolayısı ile kargaşa yaşandığı, bunu önlemek ve bu kimselerin de anlayabilmelerini sağlamak amacıyla kanunların mahalli dillere tercüme edilerek neşr ve ilan edilmesine yönelik olmuştur. Bu konuda azınlık mebusları ile Türk mebuslar arasında uzun uzadıya tartışmalar sürüp gitmiştir (MMZC., C. III, 3 Şubat 1326: 43-50). Özellikle Rum Mebus Yorgo Boşo'nun: “ ...mecliste kanunları yaparken halkın bunlar nasıl anlayacağını da düsünmeliyiz, bir genel kaide koymalıyız ve çeşitli dairelere ve nahiyelere dağıtılsın ve resmî lisandan başka mahallî dillere de tercüme edilerek ahaliye neşr ve ilan edilsin" şeklindeki önerisi üzerinde tartışmalar yoğunlaşmıştır. Konu Türk mebuslar tarafından hâkimiyet-i milliye çerçevesinde ele alınmıştır. Rum mebus Yorgo Boşo'nun önerisinin de mahzurları olacağı yönünde görüşler farklı vilayetlerden olan Türk mebuslar tarafından dile getirilmiştir. Konu hakkında son olarak konuşan Menteşe mebusu Halil Bey, " Maksat ahalinin kanunları bilmesi olunca mahallî dillere tercüme edilmesinde veya muhtelif lisanla neşredilmesinde bir beis yoktur" sözleri ile tartışmalar sona ermiştir (Özçelik, 2002: 215-220). Böylece Türkçe’nin resmî bir dil olması kabul edilmekle birlikte kanunların herkes tarafindan anlamasını sağlamak amacıyla mahalli dillere tercüme edilerek neşr ve ilan edilmesi esası kabul edilmiştir. 1910-1911 yıllarında Meclisi Mebusan'da yapılan tartışmalarda imtiyazlı veya imtiyazsız yabancı şirketlerin tüm işlem ve yazışmalarında Türkçe'nin kullanılmasına dair bir tartışmanın yapılmamış olması, bu konuda daha önce kabul gören Osmanlı telgrafhanelerinde haberleşmenin Türkçe yapılmasına dair olan 6 Nisan 1857 tarihli buyruldu ile demiryollarının inşasıyla ilgili imtiyazlı yabancı şirketlerle yapılacak yazışmaların Türkçe olmasına dair 14 Ocak 1893 tarihli düzenlemenin yürüklükte olmasından kaynaklandığı düşünülebilir. Bununla birlikte bu konudaki uygulamaların, alınan kararlara uygun olarak yürütülüp yürütülmediği tam olarak bilinmemektedir.

Bilindiği üzere II. Meşrutiyet Döneminde İttihat ve Terakki Cemiyeti devlet idaresinde söz sahibi olmuştur. Cemiyetin izlediği politikada Osmanlı'da birliğin sağlanması düşüncesi önemli bir yer tutmuştur. Ülkede birliği sağlanmanın bir yolunun da Türk Dilini geniş bir tabana yaymak olarak 
görülmüştür. Bunun için de çeşitli usullere başvurulmuştur. Dolayısı ile konu İttihat ve Terakki yönetimince millî hâkimiyet çerçevesinde düşünülerek, ele alınmıştır

I. Dünya Savaşının cephelerde yoğun şekilde yaşandığı 1916 yılında, imtiyazlı ve imtiyazsız şirketlerde tüm yazışma ve işlemlerin Türkçe yapılmasına dair bir kanunun yayınlandığını görmekteyiz. Kanun iki fasıl halinde, Takvim-i Vekayi'de 23 Mart 1916 tarihinde yayınlanmıştır ${ }^{1}$ (TBMM.Z.C., C. IV. 31.12.1339: 573). Kanunla, imtiyazlı ve imtiyazsız şirketlere Osmanlı dâhilindeki tüm haberleşme ve yazışmalarında Türkçe'yi kullanma mecburiyeti getirilmiştir. Kanuna uygun hareket etmeyenlere para cezası uygulanacağı belirtilmiştir. Böyle bir kanunun varlığı, daha önce Takvim-i Vekayi de kanunun yayınlanmış olduğu TBMM 'de yapılan tartışmalar sırasında mebuslara hatırlatılmıştır. Mecliste konunun tartışılması ve ciddiye alınması, bu dönemde Türkçe'nin yabancı şirketlerden tarafından kullanılmadığını, ihmal edildiğini veya Dünya savaşının yarattığı sıkıntılı ve gergin ortamda tatbikata konulamadığını göstermektedir ${ }^{2}$ (TBMM.Z.C., C. IV, 27.12.1339: 504-505).

\section{B- Türkiye Büyük Millet Meclisi'nde Yabancı Şirketlerle Yapılan Anlaşma ve Yazışmalarda Türkçe'nin Kullanılmasına İlişsin Tartışmalar}

Osmanlı Devleti zamanında ve TBMM'nin açılışına kadar geçen zaman içinde Türkçe'nin resmî dil olması, yaygın olarak kullanımı, yabancı şirketlerin tüm yazışma ve işlemlerinin Türkçe yapılmasına ilişkin tarihsel süreç içinde atılan adımlar ve düzenlemeler hakkında yukarıda bilgi verilmiştir. Konuya gösterilen hassasiyet TBMM.'nin açılışından sonra da devam etmiştir. Anlaşıldığı kadarı ile yabancı şirketler işlemlerinde ve resmî yazışmalarında yasa gereği Türkçe'yi kullanmaları gerekirken ihmal etmişler veya duyarlı davranmamışlardır. Bu ihmal veya duyarlı davranmama eyleminin, yeni Türkiye'nin gündeminin yoğunluğu ve henüz merkezî idarenin bu konuya el atamamış olmasıyla ilgili olduğu söylenebilir. Zira konunun mecliste yeniden gündeme getirilmesi bunu göstermektedir. Mecliste bulunan vekillerden birçoğunun daha önce Meclis-i Mebusan'da bu konunun görüşülerek bir kanunun yapıldığından haberi olmadığı anlaşılmaktadır. Bir kısmının ise TBMM 'nin açılması ile başlayan yeni dönemde konunun tekrar ele alınarak yeni bir düzenleme ile yürürlüğe konulmasının istediğini görmekteyiz. Bu bağlamda Amasya (sabık) Mebusu Ömer Lütfi Bey'in "Bilûmum şirket ve müesseselerde Türkçe lisanının istimali (kullanılması) hakkında kanun teklifi”" (TBMM.Z.C., C. II, 25.9.1339: 238) önemli bir adım olarak görülmektedir. Aşağıda, kanun teklifi ve bu konudaki meclisteki tartışmalardan söz edilecektir.

\section{1- Amasya Milletvekili Ömer Lütfi Bey’in "Bilûmum Şirket ve Müesseselerde Türkçe Lisanının İstimali (kullanılması) Hakkında Kanun Teklifi}

Son Osmanlı Meclis-i Mebusanında Amasya mebusu olarak görev yapan Ömer Lütfi Bey (Yasan), 1879 Merzifon doğumludur. 1898 de Harp Okulunu, 1902 de Harp Akademisini bitirmiştir. Trablusgarp, Balkan ve Birinci Dünya Savaşına katılmış, Erkan-1 Harp Miralay1, Kuleli Askeri İdadisi ve Tıbbiye İdadisi Ders Nazırı, Erzurum III. Ordu Menzil Müfettişi ve Yıldırım Orduları Grubu İdare Başkanı, Harp Kömür Şubesi Müdürü olmak üzere çeşitli görevlerde bulunmuştur.

\footnotetext{
${ }^{1} 10$ Mart 1332/ 23 Mart 1916 tarihli Kanun 9 madde olup, özetle; 1. madde: Demiryollarla müessasatı Nafia vesairede işletmeye ait tüm muamelat ve muhaberat yalnız Türkçe icra olunur. 2. madde: Bu hükmün uygulanması Nafia Nezaretinin şirketlere tebliğ edeceği güne kadar uygulamaya konulacaktır. Yalnız Demiryolları şirketi için bu süre 10 Temmuz 1335/ 10 Temmuz 1919 tarihine kadar uzatılabilir. 3. madde: 2. madde hükmünü, belirlenen güne kadar yerine getirmeyen şirketlerin işletmeleri hükümet tarafından geçici olarak işgal edilerek, kanunun gereği yapılır. 4. madde: İmtiyazsız her türlü Osmanlı şirketleri haberleşme ve yazışmalarında ve defterlerinde Türkçe kullanırlar. 5. madde: Ticaret Nezaretine kayıtlı ecnebi şirketler için bu mecburiyet hükümetle olan yazışmalarda da geçerli olacaktır. 6. Madde: Belirtilen tarihe kadar kanun hükmüne uygun hareket etmeyenler mahkemeye sevk olunarak 5 liradan 50 liraya kadar cezaya mahkûm olurlar. 7. Madde: Bu kanunun uygulaması bir nizamnameye öre yapılacaktır.8. madde: Kanun ilanında itibaren geçerlidir. 9. Madde: Kanunun icrasına Adliye, Nafia ve Ticaret Nazırları memurdur.

2 TBMM'de 23 Aralık 1923 tarihinde yapılan görüşmede İktisat Vekili Hasan Bey (Trabzon), I. Dünya Savaşı nedeniyle kanunun tatbikata konulamadığın ifade etmiştir.
} 
Kurmay Albay rütbesinde iken askerlikten ayrılmıştır. Son Osmanlı Mebuslar Meclisine IV. dönem Amasya mebusu olarak seçilmiştir. Osmanlı Mebuslar Meclisinde İdare Memurluğu görevinde bulunmuş, meclis kapatılınca yeni açılan TBMM'de I. Dönem Milletvekili olarak görev almıştır. Bu devrede Millî Müdafaa Vekâleti Askerî Levâzım Umumiye Reisi ve Nâfia Encümeni Reisliği görevinde bulunmuştur. Yerli ve yabancı birçok madalyaya sahip olan Ömer Lütfi Bey 12.03.1956' da vefat etmiştir (www.tbmm.gov.tr/develop/owa/milletvekillerimiz;www.biyografya.com). Kısa biyografisini verdiğimiz Ömer Lütfi Bey'in, meclis çalışma faaliyetleri kapsamında meclise sunduğu "Bilûmum şirket ve müesseselerde Türkçe lisanının istimali (kullanılması) hakkında kanun teklifi" o dönemin yoğun gündeminde önemli bir yer tutmuştur. Dolayısı ile çalışmamızın konusunu oluşturmuştur.

Genel olarak bir değerlendirme yaptığımızda, Kurtuluş Savaşı Kazanılmış, Lozan Anlaşması yapılmış, batı emperyalizmine karşı yürütülen mücadele başarı ile sonuçlanmıştır. Ardından Cumhuriyet ilan edilmiş, sıra ilan edilen Cumhuriyet'in kurumsallaşmasına gelmiştir. Bu çerçevede üzerinde özenle durulmamış, uzun yıllar ihmal edilmiş Türk Diline gerekli saygınlığın kazandırılması ve önem verilmesi kaçınılmaz olmuştur. Aslında, konu ile ilgili Osmanlı Mebuslar Meclisinde daha önce kabul edilmiş ve yürürlükte olan bir kanun vardır. Bu kanun iki fasıl halinde, Takvim-i Vekayi'de 23 Mart 1916 tarihinde yayınlanmıştır. Konunun tekrar mecliste gündeme getirilmesi ve kanun teklifinde bulunulması, bu kanunun gereği gibi uygulanmadığını, ihmal edildiğini veya savsaklandığını düşündürmektedir. Böylesi bir ihtimalin yaşanması söz konusu olmuş olacak ki konu yeniden Amasya Milletvekili Ömer Lütfi Bey tarafından meclis gündemine taşınmıştır. Ömer Lütfi Bey, konu ile ilgili kanun teklifini 6 Şubat 1923 tarihinde meclise sunmuştur ${ }^{3}$ (Çetintaş, 2019: 1076-1077). Ertesi gün gündeme alınan teklif, Tasarı İnceleme Komisyonuna gönderilmiştir. Komisyonda incelenen teklif müzakere edilmeye uygun görülmüş ve bu doğrultuda hazırlanan rapor meclise sunulmuştur. Söz konusu tasarının, meclisin 17 Şubat günü yapılan toplantısında başkan vekili Hüseyin Avni Bey tarafindan İktisat, Nafia ve Dışişleri komisyonuna havale edileceği bildirilmiştir. Kendisinin Nafia Komisyonunun Reisi olması dolayısı ile tasarının komisyonlara gönderilmesine gerek olmadığ 1 yönünde söz alan Ömer Lütfi Bey'in bu talebi başkan vekili tarafından kabul edilmemiştir. Konu ile ilgili olarak Gaziantep mebusu Ali Cenani Bey, daha önce yapılmış bir kanunun varlığından söz ederek yeni bir kanunun yapılmasına gerek olmadığına işaret etmiştir. Mecliste konunun gündeme alınıp tartışılmaya başladığı bu sürecin ardından TBMM'de Nisan ayında erken seçim kararı alınmış, dolayısı ile kanun teklifi komisyonlarda görüşülememiştir. Haziran- Temmuz 1923 tarihleri arasında yapılan 1923 seçimlerinde teklif sahibi Ömer Lütfi Bey, mecliste vekil olarak yer almamıştır (Olgun, 2011: 12). Bununla birlikte onun kanun teklifi, meclisin 27.12.1339/1923 oturumunda gündeme alınmıştır (Çetintaş, 2019:1076). Bundan sonra, daha önce konuya ilişkin bir kanunun var olduğu o nedenle yeni bir kanun yapılmasına gerek olmadığ yönündeki görüşler ile kanun var ise ahkâmına uyulup uyulmadığının tespit edilmesine yönelik tartışmalar yapılmıştır. Konu ile ilgili olarak yapılan tartışmalar ve bu meyanda dile getirilen görüşlere aşağıda yer verilmiştir.

\section{2- Bilûmum Şirket ve Müesseselerde Türkçe Lisanının Kullanılması Hakkında Kanun Teklifi Üzerinde Tartışmalar}

I. Dönem Amasya Milletvekili Ömer Lütfi Bey'in, 6 Şubat 1923 tarihinde TBMM'ne "Bilûmum şirket ve müesseselerde Türkçe lisanının kullanılması hakkında kanun teklifini" sunduğunu, ancak tasarının tam olarak müzakere edilemediğini, seçimler dolayısı ile bir müddet ertelendiğini yukarıda kısaca belirtmiştik. Tasarı, yaklaşık 7 ay sonra 25 Kasım 1923 tarihinde meclis gündemine tekrar gelmiş, ancak üzerinde müzakere yapılmamıştır (TBMM.Z.C., C. II, 25.9.1339:

\footnotetext{
${ }^{3}$ Kanun teklifinin veriliş tarihi, 27.12.1339/1923 tarihli Meclis Zabıtlarında 6 Şubat 1335/1919 olarak yazılmıştır. Bu tarihte teklif sahibi Ömer Lütfi Bey henüz milletvekili değildir. Bu nedenle kanun teklifinin yapıldığı tarih Zabıtlara sonradan yanlışlıkla 1335/1919 olarak yazılmış olabilir.
} 
238). Daha sonra söz konusu tasar1 27.12.1339/1923 tarihinde yapılan 75. oturumda meclis gündemine alınmıştır (TBMM.Z.C., C.IV, 27.12.1339: 503). Nafia Encümeninden meclis başkanlığına sunulan mazbatada, (sabık) Amasya Mebusu Ömer Lütfi Bey'in daha önce verdiği, şirketlerde Türkçe'nin kullanılması hakkındaki kanun teklifine ve bağlantılı olarak konunun müzakere yapılmasına lüzum görülmediğine işaret edilmiştir. Bununla birlikte Ömer Lütfi Bey'in teklifi meclis başkanlığınca gündeme alınmış ve üzerinde müzakere yapılmıştır. Riyaset-i Celileye (Meclis Başkanlığına) sunulan kanun teklifinde özetle; "Bilumum şirket ve müessesatta Türkçe Lisanının kabulü hakkında tanzim ve ekte takdim ettiğim kanun teklifi ile gerekçesini yüce meclise arz ve acilen müzakeresini rica ederim" denilmiştir. Sunulan tasarının gerekçesi (Esbab-1 Mucibe Lâyihası) ile çıkması istenen kanun, Lâyiha-i Kanuniye başlığı ile meclis başkanlığına arz edilmiştir. Kanunun gerekçesi sadeleştirilmiş şekliyle şu şekilde beyan edilmiştir:

\begin{abstract}
"Memleketimizde millî ve iktisadî istiklâlimizin muhafazası ve devamı için bu kadar kan ve emek sarfettik. İktisaden milletimizin yükselmesi için mevcut hallerden biri de lisan meselesidir. Tüm büyük şirketlerde işlemlerin yabancı dilde yapılması Türk gençlerine bu müesseselerin kapılarını kapalı tutmaktadır. Gerek İstanbul'un vaziyeti ve gerekse ordunun er geç terhis olacak yedek subaylarına iş bulmak meselesi bu vaziyeti daha ehemmiyetle göz önüne almayı zorunlu kılmaktadır. Binaenaleyh bu husustaki kanun teklifinin acilen müzakere ve kabulünü arz ve teklif ederim” (TBMM.Z.C., C. IV, 27.12.1339: 503).
\end{abstract}

Hazırlanan Layiha, Meclis başkanlığına aşağıdaki şekilde arz edilmiştir.

\title{
Kanun Lâyihas1
}

"Madde 1. Türkiye Büyük Millet Meclis Hükümeti hududu dâhilinde bulunan bilûmum Anonim ve sermayesi eshama münkasem (hisseli) şirketlerin ve banka ve saire gibi bilûmum müessesatı iktisadiyenin ve Dûyunu Umumiye İdaresinin muamelât ve hesabat defatiri Türkçe Lisanı ile cereyan eder.

Madde 2. İşbu kanun üç ay sonra geçerlidir.

Madde 3. İşbu kanunun icrasına Maliye ve İktisat ve Nafia vekilleri memurdur" (TBMM. Z.C., C. IV, 27.12.1339: 503).

Sunulan kanun teklifinde kısaca, tüm şirketlerin her türlü yazışma ve işlemlerinde Türkçe'nin kullanılması istenmiş ve bu isteğin uygulanabilmesi için de konunun mecliste görüşülmesi ve gereken yasanın yapılması talep edilmiştir.

Bu kapsamda konu mecliste görüşülmeye başlanmıştır. 27.12.1339/1923 tarihli oturumda konu hakkında söz alan Nafia Encümeni Reisi Cavid Paşa (Canik), daha önce bilûmum şirketlerde Türkçe lisanının kullanılması için kanun yapıldığını, şirketlerin lisanımızı kullandıklarını, bu nedenle konu üzerinde tartışma yapılmasına lüzum olmadığını ifade etmiştir. Bu görüşe karşı, Bozok Mebusu Süleyman Sırrı Bey ve Çorum Mebusu Münir Bey, meclisin kanunu yeniden düzenlemesinin yararlı olacağını ve önceden kabul edilmiş bir kanun varsa bunun tatbikatı ahkâmına gayret edilmesi gerektiğini ifade etmişlerdir (TBMM.Z.C., C. IV, 27.12.1339: 504). Bu doğrultuda sürdürülen tartışmalar sırasında bir kısım vekil, kanun olmasına rağmen şirketlerin buna uymadığını, bankaların bazısında çek ve poliçelerin Türkçe olmadığı, hatta bu durumun İktisat vekili Mahmut Esad Bey’e şikâyet edildiğini belirtmişlerdir. Benzer şekilde İktisat Vekili Hasan Bey, "Harbi Umumide böyle bir kararname şeklinde bir şey vard. Fakat mevkii tatbikata konulmadı̆̆ını" ( TBMM.Z.C., C. IV, 27.12.1339: 504-505) ifade ederek kanun değil bir kararnamenin varlığından ve uygulanmadığından söz etmiştir. Gündemle ilgili olarak söz alan Karesi mebusu Vehbi Bey kanunun var olduğunu o dönemde kendisinin Dâhiliye ve Ziraat Encümenlerinde bulunduğunu, kimi vekillerin bu hatırlamadığını beyan etmiştir. Konuşmasının devamında Vehbi Bey söylenen kanunla, teklif edilen kanunun birlikte telif edilmek üzere Dâhiliye Encümenine havale edilmesini, orada incelenmesini, kanunun uygulanıp uygulanmadığının gelecek oturuma kadar tespitinin yapılarak sonucun 
bildirilmesini, encümen adına meclis başkanlığına arz etmiştir. Bu tartışmaların ardından meclis başkanı, mevcut kanun ile teklif edilen kanunun incelenmesi maksadıyla Dâhiliye Encümenine havalesini oylamaya sunmuş ve kabul edilmiştir (TBMM.Z.,C, C. IV, 27.12.1339: 505)

Konu ile ilgili hazırlanan layiha üzerine 4 gün sonra 31.12.1399/1923 tarihinde mecliste müzakerelere tekrar devam edilmiştir. Dâhiliye Encümenine havale edilen konu üzerinde encümenin almış olduğu 30.12.1399/1923 tarih ve 42 sayılı karar meclis başkanlığına sunulmuştur. Kararda, I. Büyük Millet Meclisi üyelerinden (sabık) Amasya Milletvekili Ömer Lütfi Bey tarafından teklif edilerek müzakere edilen kanun tasarısının, bu kapsamda bir kanunun var olması nedeniyle ret edilmesine dair encümen mazbatasının meclise sunulduğu belirtilmiștir. Kanun üzere yapılan görüşmelerde İktisat Vekili Hasan Bey tarafından " bu bapta bir kararname var ise de tatbik edilmediği” ifadesinden hareketle 1332/1916 tarihinde neşrolunan kanun ile teklif edilen kanunun karşılaştırılmasının yapılarak sonucun bildirilmesi istenmiştir. Kararın devamında 1332/1916 yılında Meclis-i Mebusan ve Ayan Meclisinde müzakere edilip kabul edilen ve Takvim-i Vekayi'de yayınlanan kanunun maksadı fazlasıyla temin ettiğinden bahsedilmiş ve hükümetin kanunu tatbik etmekte gerekli özeni göstermesi temenni edilmiş, teklifin meclis genel kurulana iadesine yer verilmiştir. Kısaca Dâhiliye Encümeni kararında, daha önce bu konuda 1332/1916 tarihli bir kanun olduğu, ancak yeteri kadar uygulanmadığı, uygulanması için hükümetin gerekli özeni göstermesi gerektiğine işaret edilmiştir (TBMM.Z.C., C. IV, 31.12.1339: 572).

Dâhiliye Encümeninin meclis başkanlığına sunduğu karar metni üzerine mecliste görüşmelere yeniden başlanmıştır. İlk söz alan Karesi Milletvekili Vehbi Bey, Amasya Milletvekili Ömer Lütfi Bey'in "Bilûmum şirketlerde Türkçe kullanılması" hakkında meclise verdiği kanun teklifinin başlangıçtan itibaren meclisteki sürecini özetledikten sonra daha önce bu konuda bir kanun olduğunu, bununla ilgili olarak da: "Biz de tetkik ettik, kanunu bulduk. Meclis-i Mebusan ve Ayandan bi'l müzakere geçmiş ve 10 Mart 1332 de o zamanın usulü icabında iradeye iktiran etmiş; 18 Mart'ta Takvim-i Vekayi'de neşrolunmuş bir kanundur" demiştir. Ardından izin isteyerek kanunu meclis genel kuruluna okumuştur ${ }^{4}$. Konuşmasında ayrıca var olan kanunda belirlenen cezaların beş katına çıkarılması ve mutlak surette uygulanması gerektiğini belirtmiştir (TBMM.Z.C., C. IV, 31.12.1339: 573).

Vehbi Bey'e konuşmasının ardından kanunun tüm imtiyazlı ve imtiyazsız şirketlerde işletmeye dair muamelatta Türkçe'nin kullanılıp kullanılmadığı sorulmuş, cevabında; imtiyazlı şirketlerin halkla olan işlemlerinde kısmen kanunun gereğine uyduğunu, fakat defterlerin Fransızca tutulduğunu ifade etmiştir. Defatir-i Esasiye diye anılan bu defterlerin, sermayedarların kendi aralarında işlemlere ait olduğundan bunların kanuna dâhil olmadığını ve bunlarda uygulamanın zor olduğunu belirtmiştir (TBMM.Z.C., C. IV, 31.12.1339: 574).

Konu hakkında İzmir Milletvekili Mahmud Celal Bey de görüşlerini şöyle açıklamıştır:

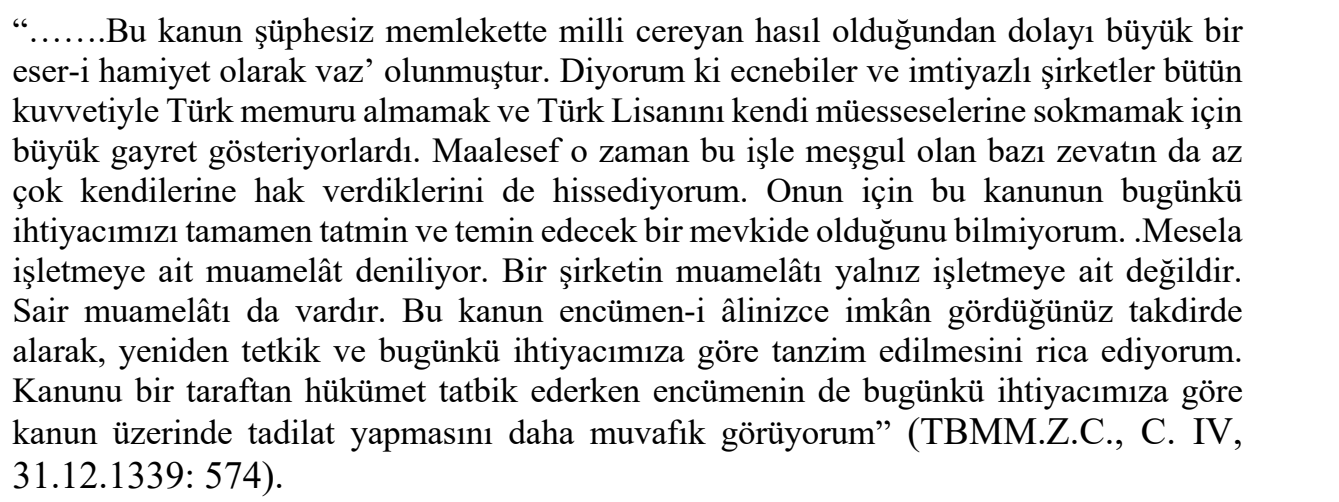

${ }^{4}$ Kanun, 29 nolu dip notta sadeleştirilerek verilmiştir. O nedenle burada yeniden verilmemiştir. 
Mahmud Celal Bey bu konuşmasında, daha önce yürürlüğe konmuş mevcut kanunun gereği gibi uygulanamadığını, kanunun yeniden gözden geçirilmesini, bugünkü ihtiyaca cevap verecek şekle getirilmesini, kısaca kanunun yeniden düzenlenmesini istemiştir.

Meclis müzakerelerinin bundan sonraki kısmında imtiyazlı ve imtiyazsız şirketlerin Türkçe Lisanını kullanıp kullanmamaları veya hangi muamelelerde kullanılacağı konusunda görüşmeler yapılmıştır. Bu bağlamda imtiyazlı şirketlerin yalnız işletmeye ait tüm muamelât ve muhaberatlarının Türkçe, işletme haricinde kendi sermayelerine ait muamelât ve muhaberatlarının kendi dillerinde yapabilecekleri ifade edilmiştir. Bu konuda söz alan Karesi Milletvekili Vehbi Bey;
“....Herhangi bir İngiliz sermayesiyle, Fransız sermayesiyle imtiyazsız olarak Türkiye dahilinde meydana gelecek şirketlerin muamelât, muhaberât, defatir ve hesabatının hepsini Türkçe yapacak. İmtiyazlı şirketlere gelince: Bunlar da yalnız işletmeye ait tüm muamelât ve muhaberât Türkçe olacaktır. İşletme haricinde kendi sermayelerine ait muamelât ve muhaberât kendi dilleri ile olacaktır. Biz bunun tatbikini kafi görüyoruz. Çünkü bu hesap hükümete ve millete taalluku olamayan bir hesaptır. Şayet bu noktada, yani onların sermayeleri hesabatı da bizim lisanımız üzerine cereyan etsin denirse ve bunu arzu ediyorsak bu bir tadildir (düzeltmedir)" (TBMM.Z.C., C. IV, 31.12.1339: 574).

diyerek, var olan kanunu imtiyazlı ve imtiyazsız şirketler açısından yorumlamıştır. Bu açılamalardan, imtiyazlı şirketlerin tüm muamelelerinde Türkçe'yi kullanmalarını sağlamak için kanunda yeniden düzenleme yapmak gerektiği anlatılmıştır. Vehbi Bey'in konuşmasından sonra söz alan Nafıa Vekili Muhtar Bey (Trabzon); Nafia Nezaretinin 1332/1916 tarihli kanunun tatbikine ciddiyetle uyduğunu, Nafia ve Demiryolları şirketlerinden başka şirketlere altı ay müddet verildiğini, verilen süreye uyulduğunu, tramvay ve elektrik şirketlerinin işlemlerinde Türkçeyi kullandıklarını, ancak Demiryolu şirketlerine 1335/1919 senesi Temmuzuna kadar süre verildiğine işaret etmiştir. Verilen sürenin bu şirketlerin teşkilatlarını oluşturmaları ve işlemleri Türkçe yapacak memurları temin etsinler diye verildiğini, bu çerçevede muallimler tutulduğunu, bazı istasyonlara özel görevli kimselerin gönderildiğini, Türkçe muamele yapacak memurlar yetiştirmek üzere çalışı1lırken verilen süre bitmeden önce mütarekenin geldiğini ve mütarekenin de her şeyi altüst ettiğini belirtmiştir. Konuşmasının devamında da o zamandan Kuva-1 Milliyenin memleketi kurtarmasına kadar kanunun uygulanmadığını, ancak sonrasında uygulandığını ifade etmiştir (TBMM.Z.C., C. IV, 31.12.1339: 575). Vekil, ayrıca kanunun tatbiki için bir nizamnamenin de yapıldığını, bazı maddelerinin yeniden düzenlenmesi için Meclis-i Mebusana gidildiğini, düzenleme teklifinin ret edildiğini de sözlerine eklemiştir.

Dönemin Nafia Vekili Muhtar Bey, mecliste yaptığı bu konuşmasında Takvim-i Vekayi'de 23 Mart 1916 tarihinde yayınlanan kanunun gösterdiği süreler dikkate alınarak uygulandığını, ancak I. Dünya Savaşı sonrası yapılan mütareke dolayısı ile her türlü nizamın bozulduğunu ve kanunda belirtilen hususlara uyulmadığını anlatmaya çalışmıştır. Ancak Milli Mücadelenin kazanılması ile kanunun yeniden uygulandığını iddia etmiştir. Bu konuda itirazlar olmuş, Gümüşhane Milletvekili Zeki Bey, Nafia Vekili Muhtar Bey'in ifadelerinin biraz belirsiz olduğunu ve kendi kanaatine göre kanunun o güne kadar tatbik edilmediğini, kanunun hiç olmazsa 1340/1924 senesinden itibaren yürürlüğe konulmasına gayret edilmesini mecliste genel kurula ifade etmiştir. Nafia Vekil'inin kanunun tatbik edildiğine yönelik sözlerine bir kısım vekiller uygulanmadığı yönünde cevaplar vermiş ve tartışmalar bu doğrultuda bir süre daha devam etmiștir. Mecliste yürütülen müzakerelere usul yönünden bakan ve değerlendiren vekiller de olmuştur. Bu bağlamda Kütahya Milletvekili Ragıb Bey, usule dair olmak üzere söz almış ve konuşmasını,

"...Elde mevcut olan kanunun tadiline ihtiyaç vardır. Ancak bu kanun Dâhiliye Encümeni ile alakalı değildir. Mesele ile doğrudan doğruya İktisat ve Nafia encümenleri alakalıdırlar ve ihtisas encümenleri onlardır. Bendenize kalırsa bir taraftan hükümet kanunun tatbikatına devam etsin, diğer taraftan da bunu bir müsvedde halinde veyahut Layiha şeklinde Meclis-i Âli şimdiden İktisat ve Nafia encümenlerine havale etsin. 
Oralarda tetkik ve tadil ciheti düşünülsün. Çünkü mesele ehemmiyetlidir”

(TBMM.Z.C., C.IV, 31.12.1339: 576).

sözleri ile tamamlamıştır. Ragıb Bey'in sözlerine katılan başka vekiller de olmuştur.

Kanun üzerinde tartışmalar yapılırken usulle ilgili başka söz alan vekiller de olmuştur. Bunlardan bir diğeri Karesi Milletvekili Vehbi Bey’dir. O, bu kapsamdaki görüşlerini şu şekilde ifade etmiştir:

“...Efendim bu kanunun buraya gelmesi tadil(düzeltme) ve saire için değildir. Kanun yok denildi ve aynı vekâlette bazı vekil haberdar olmuş tatbik etmiş, bazısı ise haberdar olamamıştır. Şimdi şifahî bir teklif üzerine tadili için kanunu falan yere havale etmek olamaz. Kanun mevkii mer'iyetten gider. Eğer teklif vaki ise alırlar, tetkik ederler. Tadilâtı mazbata ile bildiriler. Eğer bu kanunu böylece gönderirsek hepimizin üzerinde olduğu gibi hariçte yapacağı tesir; kanun henüz tetkiktedir, bakalım ne olacak diye tatbikten geri kalacak. Binaenaleyh tahriri bir teklifle, derlerse ki kanun derhal tatbik edilecektir, tatbikata devam olunacaktır. Bir taraftan da İktisat Encümeni tetkikatına devam edecektir denilirse belki kabul edilebilir. Yoksa böyle kürsüden şifahen giderse çok yanlış bir yol olur" (TBMM. Z.C., C. IV, 31.12.1339: 576).

Vehbi Bey, bu konuşması ile kanunun eksiği veya anlaşılmaz yeri varsa bunun için teklif sunulmasını, bunun da yazılı olarak yapılmasını istemiştir.

Anlaşılan meclis genel kurulunda uzun süre, önceden bir kanunun var olup olmadığ1, uygulanıp uygulanmadı̆̆ 1 , ne zaman yürüklükte olduğu, bunlara ilave olarak kanunun tetkik edilmesi, yeniden düzenlenmesi ile görüşmelerin usul yönünden doğru olup olmadığ 1 yolunda tartışmalar yapılmışıtır. Nihayet Meclis başkanı, bu tartışmaları sona erdirmek ve çözüm üretmek maksadıyla var olduğu kabul edilen kanunun encümene havale edilerek incelenmesini, yeni kanun teklifinin de dikkate alınmasını, düzenleme yapılacak tarafları varsa, ilgili encümen tarafindan düzeltmelerin yapılarak meclise getirilmesini içeren başkanlık önergesini oya sunmuştur. Oylama sonucu öneri kabul edilmiştir. Böylece mevcut kanunun eksiğinin tamamlanması ve yeni kanun teklifi de dikkate alınarak gerekli düzenlemenin yapılmasına karar verilmiştir.

Yukarıdaki açıklamalarımızdan anlaşılacağı üzere, I. Büyük Millet Meclisi üyelerinden Amasya Milletvekili Ömer Lütfi Bey tarafindan TBMM'ne verilen 6 Şubat 1923 tarihli "Bilûmum şirket ve müesseselerde Türkçe lisanının istimali (kullanılması) hakkında kanun teklifi” meclis genel kurulu tarafindan dikkate alınmış, ancak böyle bir kanunun var olduğundan hareketle yeni bir kanunun yapılması yoluna gidilmemiştir. Meclis müzakerelerinde önce, kanunun olup olmadı̆̆ 1 , var olanın kanun mu yoksa kararname mi olduğu, ardından da daha önceden var olduğu kabul edilen kanunun uygulanıp uygulanmadığı üzerinde tartışmalar yapılmıştır. $\mathrm{Bu}$ kapsamda yürütülen tartışmalar sonunda Takvim-i Vekayide yayınlanan 1322/1916 tarihli kanunun yürürlükte olduğu, ancak çeşitli sebeplere bağlı olarak tam anlamıyla uygulanamadığı sonucuna varılmıştır. Dolayısı ile kanunun var olmasına rağmen uygulanmayışı durumu, konunun meclis gündemine getirilmesine yol açmıştır. $O$ günlerin iş yoğunluğunda bilûmum şirket ve müesseselerde Türkçe Lisanının kullanılması konusunun önemsenerek kanun teklifi olarak meclise getirilmesinde ve gündeme alınmasında Amasya Milletvekili Ömer Lütfi Bey’in önemli ölçüde katkıları olmuştur.

Türk Dilinin kullanılması, Türkçe konuşulması ve Türkçe'nin resmî dil olması meselesi bundan sonraki süreçte Anayasalarda yer alan hükümlerle bir düzene sokulmuştur. İlk kez Türk Devleti’nin resmî dilinin Türkçe olduğu 1921 Anayasasının 2. Maddesinde 29 Ekim 1923 günü 
yapılan değişiklikle düzenlenmiştir ${ }^{5}$. Bir sonraki 1924 Anayasasının 2. maddesinde ${ }^{6}, 1961^{7}$ ve 1982 de kabul edilen anayasalarımızın her ikisinin de 3. maddesinde "Türkiye Devleti ülkesi ve milleti ile bölünmez bir bütündür. Resmî Dili Türkçedir" hükmü yer almıştır. 1982 Anayasasının 4. Maddesinde, 3. maddede yer alan hükümlerin değiştirilemeyeceği, değiştirilmesinin teklif edilemeyeceği yer almıştır (1982 Anayasas1, 2001: 30). Böylece Türkçe'nin resmî dil olması ve kullanımı anayasanın güvencesi altına alınmıştır.

\section{Sonuç}

Tarihi kayıtlara bakıldığında Türk Tarihinde, ülke topraklarında Türk Dilinin kullanılması, korunması ve resmî bir dil olması yolundaki ilk girişimlerin, Anadolu Selçuklu Sultanı II. İzzeddin Keykavus (1246-1261) zamanında başlatıldığı görülmektedir. Benzeri bir hassasiyet, yakın bir süre sonra Karamanoğlu Mehmet Bey'in 1277 de Konya'y1 ele geçirdiğinde "Dergâh ve Bargâhda, mecliste ve meydanda Türkçeden başka dil konuşulmayacağına" ilişkin fermanı ile gösterilmiştir. $\mathrm{Bu}$ girişimlerden tam bir başarı elde edildiğini söylemek zordur. Fakat bu girişimlerin Anadolu Beyliklerinin Türk Dili konusundaki hassasiyetini, genel tutumunu, kültür seviyelerini, devrin sosyal ve siyasi konumunu tespit bakımından kayda değer olduğunu söylenebilir.

Osmanlı Devletinde özellikle Tanzimat döneminde, kapitülasyonların sağladığı imkân ve imtiyazlarla yabancıların ticari alanda söz sahibi olmaları hali, ülkede farklı yabancı dillerin de kullanılmasına yol açmıştır. Bu ise onların her türlü işlemlerinde kendi dillerini kullanmalarına ve serbestçe hareket etmelerini sağlamıştır. İkili anlaşmalara dayalı yazılı metinlerin yalnızca yabancı dilde hazırlanması bürokraside birçok sorunu beraberinde getirmiştir. Anlaşmada geçen hükümlerin yanlış anlaşılmasına, yabancı şirketlerin konuyu kendi çıkarlarına göre yorumlamalarına sebebiyet vermiştir. Bu tür olumsuzluklar çoğu zaman ekonomik açıdan zararlara neden olmuştur. Bunun önlenmesi için anlaşma metinlerinin bir nüshasının yabancı şirketlerin mensup olduğu devletin resmî dili ile diğerinin ise Türkçe yapılması kararlaştırılmıştır. Bu adımla, anlaşmada geçen hükümlerin yanlış anlaşılmasına ve yabancı şirketlerin konuyu kendi çıkarlarına göre yorumlamalarının önüne geçmek hem Türkçeyi etkin hale getirmek hem de dil ile bağımsızlık arasında var olan bağı güçlendirilerek millî hassasiyet ortaya konmaya çalışılmıştır.

Yabancı şirketlerle yapılan anlaşma metinlerinin Türkçe olması şartının getirilmesi yanında Osmanlı'nın ilk anayasası olan Kanun-1 Esasi'nin taslak ve asıl metninde Türk Dili'nin kullanılması ve resmî dil kabul edilmesine yönelik hükümler konmuştur. Türkçe'nin konuşulması ve kullanılmasına dair tartışmalar II. Meşrutiyet döneminde de devam etmiştir. Bilindiği üzere II. Meşrutiyet Döneminde İttihat ve Terakki Cemiyeti idarede söz sahibi olmuştur. Cemiyetin izlediği politikada Osmanlı'da birliğin sağlanması önemli bir yer tutmuştur. Birliği sağlanmanın bir yolunun da Türk Dilini geniş bir tabana yaymak olarak görülmüsşür.

Meclis-i Mebusan' da bu dönemde yapılan tartışmalar, genellikle Türkçe'nin resmî dil olması ile ilgili olup, ana dili Türkçe olmayanların meclisten çıkan kanunları anlayamadıkları, dolayısı ile kargaşa yaşandığı, bunu önlemek ve bu kimselerin de anlayabilmelerini sağlamak amaciyla kanunların mahalli dillere tercüme edilerek neşr ve ilan edilmesine yönelik olmuştur. Bu gelişmelerin ardından nihayet I. Dünya Savaşı'nın devam ettiği günlerde Türkçe'nin konuşulması, kullanılması, imtiyazlı ve imtiyazsız şirketlerin tüm yazışma ve işlemlerinin Türkçe yapılmasına dair bir kanunun yayınlanmıştır. 23 Mart 1916 tarihinde Takvim-i Vekayi'de yayınlanan kanunla, imtiyazlı ve

\footnotetext{
${ }^{5}$ Teşkilatı Esasiye Kanunu, Kanun No: 85, Kabul Tarihi: 20/1/1337 (1921); Değişiklik tarihi, 29.10 .1339 (1923) tarih ve 364 sayılı kanun 2. Madde, www. anayasa.gov.tr/tr/ mevzuat/önceki-anayasalar/1921-anayasas1/ Erișim: 16/.04.2020. ${ }^{6}$ Teşkilatı Esasiye Kanunu, Kanun No: 491, Kanun Tarihi 20.4.1340/1924; Değişiklik tarihi, 10.4.1928 tarih ve 1222 sayılı kanun 1. Madde, www. anayasa.gov.tr/ mevzuat. Erişim: 16.03.2020.

7 Türkiye Cumhuriyeti Anayasası, Kanun No: 334, Kabul Tarihi: 09.07.1961, www. anayasa.gov.tr/ mevzuat. Erişim: 16.03.2020.
} 
imtiyazsız şirketlere Osmanlı dâhilindeki tüm haberleşme ve yazışmalarında Türkçe'yi kullanma mecburiyeti getirilmiştir.

23 Mart 1916 tarihli Takvim-i Vekayi'de imtiyazlı ve imtiyazsız şirketlere Osmanlı dâhilindeki tüm haberleşme ve yazışmalarında Türkçe'yi kullanma mecburiyeti getiren bir kanunun olmasına rağmen, uygulamada buna riayet edilmediği anlaşılmaktadır. Mecliste yapılan tartışmalar ile savaş döneminin yarattığı etki ve savaş sonrası mütareke ortamına bağlı olarak her türlü nizamın bozulması nedeniyle kanunda belirtilen hususlara uyulmadığının Nafia Vekili tarafından ifade edilmesi bunu kanıtlamaktadır. Bundan dolayıdır ki Son Osmanlı Meclis-i Mebusanında Amasya mebusu olarak bulunmuş, Mebuslar Meclisi kapanınca yeni açılan TBMM'ye I. Dönem Milletvekili olarak seçilmiş Ömer Lütfi Bey, meclis çalışma faaliyetleri kapsamında 6 Şubat 1923 tarihinde "Bilûmum şirket ve müesseselerde Türkçe lisanının istimali (kullanılması) hakkında kanun teklifi" vermiş̧tir. II. Dönem T.B.MM. seçimleri dolayısı ile kanun teklifi hemen gündeme alınmamış, yaklaşık 7 ay sonra kendisinin milletvekili olarak bulunmadığı mecliste 25 Kasım 1923 tarihinde gündeme alınmıştır. Tüm bu gelişmeler bize, 1916 yılında kabul edilen "Bilûmum şirket ve müesseselerde Türkçe lisanının kullanılması hakkında" bir kanunun olduğunu, ancak çeşitli nedenlerle uygulanmadığını, bu haliyle 1923 yılana gelindiğini, bu durumun ise artık doğal karşılanmadığını, bu nedenle meclis gündemine getirildiğini göstermektedir.

Ömer Lütfi Bey tarafından meclise sunulduğunu ifade ettiğimiz "Bilûmum şirket ve müesseselerde Türkçe lisanının kullanılması hakkındaki" kanun tasarısı nihayet gündeme alınmış, farklı günde yapılan iki ayrı oturumda tartışılmıştır. Tartışmaların ilk kısmında, daha öncesi bu yollu bir kanunun var olup olmadığı, var ise bunun kanun mu kararname mi olduğu, uygulanıp uygulanmadığ mahiyetinde devam eden tartışmaların sonucunda, 23 Mart 1916 tarihli Takvim-i Vekayi'de yayınlanan bir kanunun var olduğu bilgi sahibi vekiller tarafından ortaya konmuş, buradan bir kısım vekillerin bu durumdan hiç haberdar olmadıkları anlaşılmıştır. Kanun var olmakla birlikte uygulanmayışı üzerinde tartışmalar yapılmış, uygulanamama nedeninin hem savaş ortamının yarattığı olumsuzluk hem de mütareke ortamının gerginliği olarak ifade edilmiştir. Tüm bunların sonunda meclis başkanı, bu tartışmaları sona erdirmek ve meseleyi çözüme kavuşturmak amacıyla, kanunun yürüklükte olması sebebiyle yeni bir kanun yapılamayacağı, ancak var olan kanun eksikliklerinin tespiti ve yeni önerilen tasarının da gözden geçirilmesini, düzeltilecek tarafları varsa ilgili encümene havale edilmesini, encümen tarafindan düzenlemeler yapıldıktan sonra da meclise getirilmesini oya sunmuştur. Sonuçta mevcut kanunun eksikliğinin tamamlanması, yeni tasarının gözden geçirilmesi ve gerekli düzenlemenin yapılması kararı alınmıştır.

Uygulamas1 ihmal edilen veya unutulan önemli bir konunun meclis gündemine taşınmasında, bu konuda oldukça hassasiyete sahip olduğunu düşündügümüz ve o günün ulus devlet yapılanması çerçevesinde sahip olunan düşünceye bağlı olarak hareket eden milletvekillerimizden, Amasya Milletvekili Ömer Lütfi Bey'in kuşkusuz önemli rolü olmuştur. Bu doğrultudaki girişimi ve konuya gösterdiği hassasiyeti, günün gereklerini yerine getirme çabası olarak görülmekle birlikte eksik görülen bir uygulamanın tamamlanması veya yerine getirilmesini sağlamak olarak da değerlendirilebilinir. Tüm bunlar milletvekilinin duygu, düşünce, hassasiyeti ve kişiliğinin tanınmasına da imkân sağlamaktadır. Verilen kanun tasarısı ile konunun TBMM.'nde görüşülmesinde, ihmallerin giderilmesinde, konunun gündeme alınarak istenen amaca doğru yol alınmasında Ömer Lütfi Bey'in katkısının önemli olduğunu ifade edebiliriz. Diğer taraftan Ömer Lütfi Bey'in "Bilûmum şirket ve müesseselerde Türkçe lisanının kullanılmasına" dair kanun tasarısı ve bundan beklentileri, sonraki dönemde yapılan tüm anayasalara bir boyutu ile yansımıştır. Bu tarihten sonra yapılan tüm anayasaların ilk üç maddesinden birinde "Türkçe'nin Resmî Dil" olduğu hükmü yer almış, diğer bir madde ile de bu hükmün değiștirilemeyeceği ifade edilmiștir. Bu bağlamda Ömer Lütfi Bey'in meclise sunduğu kanun tasarı ile başlatılan tartışmaların, Türkçe'nin 
resmî dil olması ve Türkçe ile ilgili hükmün anayasaya girmesine önemli ölçüde katk1 sunduğunu söyleyebiliriz.

\section{Kaynakça}

\section{1- Arşiv Kaynakları}

Başbakanlık Osmanlı Arşivi (BOA), Hariciye Nezareti Tercüme Odası (HR. TO.), 371/108.

Başbakanlık Osmanlı Arşivi (BOA), Hariciye Nezareti Mektûbî Kalemi (HR. MKT.), 185/33.

Başbakanlık Osmanlı Arşivi (BOA), Bâb-1 Evrak Odası, (BEO), 139/10353.

Başbakanlık Osmanlı Arşivi (BOA), Meclis-i Vükelâ, (M.V), 199/18.

Başbakanlık Osmanlı Arşivi (BOA), Şura-1 Devlet (Ş.D), 512/1.

\section{2- Meclis- Mebusan ve TBMM. Zabitları}

MMZC. C.6, Devre 1, İçtimai 1, 25 Mayıs 1326/7 Haziran 1910

MMZC. C.3, Devre 1, İçtimai 3, 3 Şubat 1326/16 Şubat 1911

TBMM.Z.C., C.4, 2. Dönem, 77. Bileşim, 31.12.1339.

TBMM.Z.C., C.4, 2. Dönem, 75. Bileşim, 27.12.1339.

TBMM.Z.C., C. 2, 2. Dönem, 25. İçtima, 25.9.1339/1923.

\section{3-Araştırma Eserler ve Makaleler}

Acar, İ. (2013). Devlet dili Türkçe ve azınlık dil hakları. Liva Yayınları.

Ayverdi, S. (1976). Milli kültür mes'eleleri ve maarif davamız. Kültür Bakanlığı Yayınları.

Banarlı, N. S. (1983). Resimli Türk edebiyatı tarihi. Milli Eğitim Basımevi.

Ergin, O. (1977). Türk maarif tarihi. C.1. Eser Matbaas1.

Erişen, S. (1979). “Ulusal bağımsızlık ve dil.” Türk Dili, 337: 200-205.

Günalan, R. (2016). "Tanzimat sonrasında Osmanlı Devleti'nde yabancı şirketler tarafindan yürütülen iş ve işlemlerinde Türkçenin kullanımı meselesi." Avrasya İncelemeleri Dergisi (Journal of Eurasian Studies), 5/2: 341-363.

Karluk, R. (1997). Türkiye ekonomisi. Beta Basım Yayım Dağıtım.

Kili, S., Gözübüyük, Ş. (1985). Türk anayasa metinleri. Türkiye İş Bankası Kültür Yayınları.

Korkmaz, Z. (2017a). "Cumhuriyet döneminde bir kültür dili olarak Türkçe.” Türk Dili Üzerine Araştırmalar, Türk Dil Kurumu Yayınları. 2: 652-660.

Korkmaz, Z. (2017b). “Anadolu beylikleri döneminde Türk dili ve karamanoğlu mehmed bey”, Türk Dili Üzerine Araştırmalar, Türk Dil Kurumu Yayınları.1: 424-428.

Olgun, K. (2011). “Türkiye'de cumhuriyetin ilanından 1950'ye genel seçim uygulamaları.” Atatürk Araştırma Merkezi Dergisi, 27/ 79: 1-35.

Özçelik, A. (2002). “Osmanlı mebusan meclisi'nde “Türkçe” tartışması.” Otam, 13: 213-226.

Şimşek T. (2014). "Türkçe'nin resmî dil olması ve doğru kullanımının kanunla korunması." Uluslararası Sosyal Araştırmalar Dergisi (The Journal of International Social Research), 7/29 (7): 738-749.

Tan, T. (1967). "Osmanlı imparatorluğunda yabancılara verilmiş kamu hizmeti imtiyazları." Ankara Üniversitesi Siyasal Bilgiler Fakültesi Dergisi, XXXII/2: 285-326. 
Turan, O. (1979). Türk cihan hâkimiyeti mefkûresi tarihi,(2), 3. Baskı. Nakışlar Yayınevi.

Teşkilatı esasiye kanunu, Kanun no: 491, Kanun Tarihi 20.4.1340/1924.

Teşkilatı esasiye kanunu, Kanun No: 85, Kabul Tarihi: 20.1.1337 (1921); Değişiklik tarihi, 29.10.1339 (1923)

Türkçe sözlük (1998), Türk Dil Kurumu Yayınları, C.1, 9. Bask1.

1961 Türkiye Cumhuriyeti anayasası, Kanun No: 334, Kabul Tarihi: 09.07.1961

1982 anayasası, (2001 Değişiklikleri ile), Serhat Yayınları.

\section{4- Elektronik Kaynaklar}

www. tbmm.gov.tr/develop/owa/milletvekillerimiz. Erişim: 03.02.2020.

www.biyografya.com > biyografi. Erişim: 03.02.2020.

www. anayasa.gov.tr/ mevzuat. Erişim: 16.04.2020. 